Gelanggang Olahraga: Jurnal Pendidikan Jasmani dan Olahraga

Volume 2, Nomor 1, Juli-Desember 2018

e-ISSN : 2597-6567

p-ISSN : 2614-607X

DOI : https://doi.org/10.31539/jpjo.v2i1.489

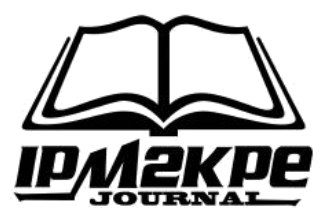

\title{
PENGARUH METODE LATIHAN SIRKUIT TERHADAP KETERAMPILAN MEMANAH
}

\author{
Arisman \\ Universitas PGRI Palembang \\ arisman9002@gmail.com
}

\begin{abstract}
ABSTRAK
Penelitian ini bertujuan untuk mengetahui pengaruh latihan menggunakan metode latihan sirkuit terhadap Keterampilan memanah Siswa Ekstrakulikuler Sekolah Dasar Islam Terpadu Auladi Kota Palembang. Jenis penelitian ini termasuk dalam kategori penelitian eksperimen semu. Populasi penelitian ini sejumlah 35 orang, sedangkan sampel ditetapkan secara purposive sampling sehingga diperoleh sampel sebanyak 24 orang siswa putra. Data diperoleh melalui tes teknik dasar dalam satuan angka. Sedangkan analisis data menggunakan teknik uji beda (uji t). Hasil analisis data menunjukkan bahwa latihan menggunakan metode latihan sirkuit berpengaruh secara signifikan terhadap peningkatan Keterampilan memanah, dimana $t_{\text {hitung }}>t_{\text {tabel }}=4,49>1,714$. Simpulan, metode latihan sirkuit secara efektif memberikan pengaruh yang positif terhadap keterampilan memanah
\end{abstract}

Kata Kunci : Metode , Latihan Sirkuit, Memanah

\begin{abstract}
This study aimed to determine the effect of training using the circuit training method on archery skill of the extracurricular students of the Auladi Islamic Primary School Palembang. This type of research was involved in the category of quasi-experimental research. The population of this study was 35 people, while the sample was determined by purposive sampling so that a sample of 24 male students was obtained. The data was obtained through basic technique test. While data analysis used independent sample t- test. The result of data analysis showed that training using the circuit training method significantly affected the improvement of archery skill, where tvalue $>$ t table $=4.49>1.714$. Conclusion, the method of circuit training effectively had a positive influence on archery skill.
\end{abstract}

Keywords:Circuit Training, Metho, Archery 


\section{PENDAHULUAN}

Olahraga merupakan bagian terpenting dalam kehidupan umat manusia di dunia dan juga kebutuhan orang banyak dalam menciptakan kehidupan yang sehat. Di zaman millenial saat sekarang ini kedudukan olahraga memegang peranan penting bukan hanya sebagai lifestyle akan tetapi sebagai faktor pemicu dalam mempereratkan hubungan antar sesama manusia, golongan, etnis dan lain sebagainya. Dalam hal ini olahraga dijadikan sebagai pemersatu bangsa maka setiap negara akan senantiasa mengembangkan nilai-nilai yang ada di dalam olahraga.

Menurut Sajoto (1988), Olahraga terbagi bermacam-macam yaitu olahraga Prestasi, olahraga pendidikan, olahraga kesegaran jasmani dan olahraga prestasi. Semua olahraga tersebut memiliki tujuannya masing-masing, olahraga rekreasi sering digunakan oleh orang banyak untuk mengisi waktu luang dan dilakukan dengan kegembiraan. Kemudian olahraga kesegaran jasmani dilakukan dalam hal ilmu pengetahuan seperti pengetahuan sosial, ilmu pengetahuan kedokteran, ilmu pengetahuan ekonomi serta lingkungan hidup yang dikerjakan dengan formal, terprogram serta diasuh oleh tenaga profesional dengan tujuan pendidikan. Kegiatan ini dilakukan secara formal yang berguna untuk mencapai sasaran pendidikan nasional yang dilakukan melalui olahraga yang tertuang dalam kurikulum.

Kemudian yang berikutnya adalah olahraga prestasi dilakukan untuk mencapai prestasi setinggi-tingginya tentang semua ilmu pengetahuan yang diolah sejak dini melalui pembibitan untuk mencapai tujuan yang telah ditetapkan. Pada dunia pendidikan, olahraga prestasi juga dilakukan melalui kegiatan ekstrakulikuler yang dilakukan diluar jam pembelajaran yang tujuannya menjaring para siswa untuk dijadikan sebagai tongkat estapet kemajuan olahraga dimasa akan datang. Kegiatan ekstrakulikuler telah banyak menaungi beraneka cabang olahraga untuk diajarkan. Salah satunya cabang olahraga panahan.

Olahraga panahan adalah olahraga yang sangat dikenal di dunia karena olahraga ini juga sudah masuk dalam event-event baik ditingkat nasional maupun tingkat internasional. Olahraga panahan ini sangat begitu diminati oleh kalangan pelajar saat ini khususnya sekolah dasar dalam hal ini bisa dijadikan sebagai pembibitan calon atlet untuk dimasa depan.

Keberadaan olahraga ini pada sekolah dasar islam terpadu auladi di kota palembang cukup membanggakan karena banyak antusias dari para siswa untuk ikut mempelajarinya dan juga sudah memiliki kemajuan yang cukup pesat dari hari kehari. Namun, disamping itu juga olahraga ini juga mengalami kendala dalam hal keterampilan yang dimiliki siswa ektrakulikuler di sekolah. Dimana, para siswa masih rendah dalam penguasaan teknik-teknik yang baik dan benar. Belum baiknya keterampilan yang dimiliki para siswa dilihat dari posisi memegang busur ataupun disaat melepaskan anak panah kesasaran masih kurang bagus, keterampilan yang kurang bagus akan membawa hasil yang tidak bagus juga.

Apabila diperhatikan dengan seksama, beberapa faktor yang menyebabkan belum baiknya keterampilan siswa dalam memanah di sekolah dasar islam terpadu auladi kota palembang diakibatkan oleh beberapa faktor yaitu faktor kondisi fisik, 
faktor frekuensi latihan, faktor sarana prasarana, faktor metode latihan dan faktor motivasi. Dari sekian banyaknya faktor, bagian faktor metode latihanlah yang banyak mempengaruhi dan menjadi pertimbangan bagi pelatih untuk menentukan mana yang paling tepat.

Metode ialah suatu cara, yang didalam fungsinya merupakan alat untuk mencapai tujuan. Makin baik suatu metode maka makin efektif juga tujuan yang ingin dicapai. Hal ini terjadi di Sekolah Dasar Islam Terpadu Auladi Kota Palembang, model latihan yang digunakan oleh pelatih tidak sesuai dengan harapan. akibatnya, kemampuan siswa dalam melakukan keterampilan memanahpun masih rendah sehingga disaat latihan dilapangan siswa cenderung tidak melakukan teknik keterampilan memanah dengan baik.

Sirkuit teknik merupakan salah satu metode latihan yang berpengaruh terhadap peningkatan teknik dan keterampilan memanah dalam pemberian bentuk latihan menggunakan pos-pos, dimana setiap pos mempunyai bentuk kegiatan yang berbeda satu sama lainnya. Dalam pencapaian tujuan latihan maka pembebanan latihan juga diharuskan sesuai dengan prinsip-prinsip latihan, oleh karenanya pemberian latihan teknik haruslah mengacu pada tujuan yang akan dicapai agar bisa membawa pengaruh terhadap peningkatan teknik serta menjadi terampil.

Kiram (1999) mengatakan bahwa keterampilan ialah suatu tindakan yang memerlukan aktivitas gerak yang harus dipelajari agar mendapatkan bentuk gerakan yang benar. Berdasarkan penjelasan tersebut, disimpulkan bahwa keterampilan berkaitan dengan satu bentuk ke bentuk lainnya. Jadi, bagaimana kualitas gerak yang ditampilkan si anak, apakah sudah tepat, efektif, efisien, lancar dan sebagainya, keterampilan memanah ialah kemampuan penguasaan teknik dasar panahan meliputi posisi berdiri (stand),nocking, extend, drawing, ancroring, tighten, aiming dan release.

Panahan merupakan salah satu cabang olahraga yang membutuhkan keterampilan yang baik, olahraga ini tidak asing bagi semua lapisan masyarakat Indonesia. Olahraga ini tidak mengenal usia, lapisan sosial masyarakat, dari orang dewasa maupun remaja bahkan sampai pada anak usia dini dan sekolah dasar. Dalam melakukan keterampilan memanah yang baik maka harus disertai dengan gerakan teknik yang bagus.

\section{KAJIAN TEORI}

Menurut Akbar (2018) mengatakan bahwasanya olahraga panahan itu adalah olahraga Ketepatan pada sasaran yang tujuannya melepaskan anak panah ke target face setepat mungkin sehingga diperlukan konsistensi yang harus dilakukan secara terus-menerus dalam latihan.

Kemudian Menurut Ahmad (2008) ada beberapa teknik yang harus dimiliki oleh seorang pemanah yaitu: 1) teknik stance ialah sikap berdiri untuk menempatkan posisi kaki dan badan dalam menghasilkan postur tubuh yang efektif dalam menghasilkan badan dalam posisi seimbang. 2) teknik Nocking merupakan penempatan anak panah pada tali (string) dengan mengeratkan bagian ujung nock dan meregangkan bagian utama panah. 3) Anchoring merupakan teknik menjangkarkan lengan sebagai penarik, posisi anchor dapat 
diklasifikasikan pada tingkatan tinggi dan rendah. Anchor yang tinggi memakai ujung jari telunjuk yang mengulur ke sudut pandangan mata sementara anchor rendah jari depan bertumpu langsung dibawah tulang rahang sehingga garis berada ditengah wajah. selanjutnya 4).teknik aiming merupakan cara melakukan bidikan pada mata kemudian mata harus dipusatkan pada tengah-tengah sasaran secara tepat. Langkah terakhir yaitu 5). follow through ialah gerak kelanjutan dari gerakan sebelumnya yang mengutamakan posisi badan, posisi lengan dan posisi kepala mempengaruhi peluncuran sampai anak panah mengarah kesasaran.

Dari beberapa pendapat diatas, dapat disimpulkan bahwasanya dalam melakukan gerakan teknik dalam memanah harus di lakukan secara sistematis, bersinambungan serta berkelanjutan dalam melakukan gerakan-gerakan teknik yang benar agar disaat melepaskan anak panah akan dengan mudah mengarah ke sasaran terbaik sehingga agar hasil yang dicapai dalam latihan bisa menjadi maksimal.

Latihan merupakan serangkaian aktifitas yang dilakukan secara teratur untuk menuju suatu tujuan yang jelas. Biasanya dalam latihan ada banyak metode atau cara dalam melakukan aktifitas latihan tersebut, salah satunya yaitu dengan menggunakan latihan sirkuit.

Menurut Fikri (2017) mengatakan bahwasanya bentuk latihan sirkuit harus dirancang sedemikian rupa dan disesuaikan dengan kebutuhan. Kemudian dalam penetapan tujuan suatu latihan itu sendiri dinilai penting pada penyusunannya serta bentuk-bentuk latihan disetiap pos juga harus diperhatikan.

Menurut Irawadi (2010) metode latihan circuit adalah "sebuah bentuk latihan yang menggunakan pos-pos, setiap pos dilakukan model latihan yang berbeda". Penjelasan teori tersebut dijelaskan bahwa latihan circuit teknik merupakan sebuah rangkaian bentuk latihan teknik-teknik, dimana setelah selesai pada satu pos, kemudian pindah berikutnya secara berurutan dan harus diberi interval waktu untuk istirahat. Latihan harus dilakukan dengan beberapa kali repetisi dalam sebuat set, antara satu set juga diberikan waktu istirahat menjelang set berikutnya. Waktu istirahat antara set lebih lama daripada waktu istirahat antara pos-pos.

Sajoto (1988) mengatakan circuit terdiri dari beberapa stasiun untuk latihan, dimana latihan-latihan itu dilaksanakan. Beban latihan lebih kurang setengah beban maksimal yang biasa dilakukan. Satu latihan circuit dikatakan selesai ketika seseorang telah menyelesaikan latihan disemua stasiun dengan pemberian dosis serta waktu yang telah ditetapkan. Program latihan circuit harus dirancang sedemikian rupa sehingga latihan yang yang akan diberikan mengenai sasaran yang dituju diharapkan tercapai.

Dari beberapa penjelasan tersebut, disimpulkan bahwa latihan circuit merupakan suatu bentuk latihan yang memiliki pos-pos, pada setiap pos latihannya berbeda-beda untuk menghasilkan perubahan bernilai positif pada kemampuan motorik seseorang. Satu latihan circuit dinyatakan selesai jika seseorang telah menyelesaikan bentuk latihan disemua stasiun dengan dosis serta waktu yang telah ditentukan. 
Pendapat di atas menjelaskan bahwa latihan circuit harus dirancang sebagus mungkin dan juga baik agar menghasilkan manfaat terhadap kemampuan seseorang. Perlu menjadi pertimbangan disaat menyusun program latihan circuit yaitu dengan menetapkan tujuan dari latihan itu sendiri, menentukan jumlah pos latihan, menyusun masing-masing pos untuk menghindari pembebanan terhadap otot yang sama dan lamanya latihan baik waktu untuk melakukan satu set latihan maupun waktu untuk latihan secara keseluruhan.

Syafruddin (2012) menyatakan bahwa "lamanya beban menunjukkan jumlah waktu suatu latihan, suatu seri latihan atau jumlah waktu untuk menyelesaikan suatu jarak tertentu". pernyataan itu menjelaskan bahwa disaat melakukan sebuah latihan agar bisa memberikan manfaat terhadap kemampuan fisik, maka perlu diperhatikan jumlah waktu yang diperlukan dalam satu kali bentuk latihan. Lamanya kebutuhan waktu untuk berlatih berbeda-beda antara satu dengan lainnya, tergolong berdasarkan tinggi rendahnya tingkat kesegaran jasmani seseorang. Dapat diartikan bahwa semakin tinggi tingkat kesegaran jasmani seseorang maka seseorang tersebut akan mampu berlatih dalam waktu yang lama.

Pemaparan di atas menjelaskan waktu minimal yang dibutuhkan dalam melakukan latihan untuk memperoleh hasil yang lebih baik berkisar antara 40-45 menit untuk setiap melakukan kegiatan inti, dan waktu pemanasan dan pendinginan harus disediakan lebih kurang 15 menit, sehingga jumlah total keseluruhan waktu dalam melakukan latihan minimal 60 menit, agar tujuan latihan tersebut bisa memberikan pengaruh yang positif terhadap peningkatan keterampilan memanah.

Adapun tahap-tahap dalam melaksanakan metode Sirkuit sebagai berikut menurut Harsono (1988) Cara pelaksanaan Sirkuit adalah Setelah lapangan dan peralatan telah dipersiapkan, kemudian setiap siswa atau atlet diberikan penjelasan tentang cara dan bentuk latihan di setiap pos untuk dilakukan. Selesai memberikan penjelasan, kemudian setiap siswa/atlet disuruh mencoba melakukan setiap bentuk latihan di setiap pos tersebut, agar dengan mudah mereka lebih mengenal setiap bentuk latihan, sehingga kesalahan ketika melaksanakannya bisa di hindari. Selesai percobaan tersebut, kemudian setiap atlet mulai melakukan latihan dan berusaha dengan sebaik-baiknya. Pelaksanaan metode latihan Sirkuit dalam penelitian ini menggunakan enam model bentuk latihan, sehingga ada variasi pada setiap sesi latihan. Maaing-masing pos/stasiun dilakukan latihan sesuai repetisi dan intensitas yang akan diberikan adalah sub maksimal yaitu $80 \%$ dari kemampuan maksimal dengan rest antar pos 30 detik dan istirahat antar set 5 menit.

\section{METODE PENELITIAN}

Jenis penelitian yang digunakan adalah Eksperimen Semu (quasi eksperimen). Tujuan penelitian ini untuk mengetahui pengaruh metode latihan sirkuit terhadap keterampilan memanah Sekolah Dasar Islam Terpadu Auladi Kota Palembang, Variabel bebas dalam penelitian ini adalah metode latihan sirkuit, Variabel terikatnya yaitu keterampilan memanah siswa ekstrakulikuler. 
Tempat penelitian dilaksanakan dilapangan SDIT Auladi Lama penelitian yaitu 16 kali pertemuan, penelitian dilaksanakan selama dua bulan dengan frekuensi pertemuan tiga kali dalam seminggu dan waktu pertemuan adalah 90 menit dalam setiap pertemuan.

Populasi penelitian ini adalah siswa SDIT Auladi berjumlah 35 orang yang mengikuti kegiatan ektrakurikuler panahan. Teknik penarikan sampel menggunakan teknik purposive sampling yaitu berdasarkan pertimbanganpertimbangan tertentu maka, Jumlah sampel yang akan dilakukan berjumlah 24 orang siswa Putra.

Tabel1

Data siswa

\begin{tabular}{lllll}
\hline \multirow{2}{*}{ No } & \multirow{2}{*}{ Kelas } & \multicolumn{2}{l}{ Jenis kelamin } & Jumlah \\
\cline { 2 - 4 } & & Putra & Putri & \\
\hline 1 & Kelas V & 14 & 5 & 19 \\
\hline 2 & Kelas VI & 10 & 6 & 16 \\
\hline Jumlah & 24 & 11 & 35 \\
\hline
\end{tabular}

\section{HASIL PENELITIAN}

Data Hasil Tes Awal Keterampilan memanah sebelum diberikan perlakuan dengan metode sirkuit yang telah dikemukakan di halaman sebelumnya. ditemukan yang memiliki keterampilan memanah dengan skor diatas rata-rata sebanyak 12 orang (50\%) dan skor dalam rata-rata yaitu hanya 2 orang $(8,33 \%)$. Sedangkan untuk dibawah skor rata-rata ditemukan 10 orang $(41,67 \%)$.

Data Hasil Tes Akhir Keterampilan memanah Metode Latihan Sirkuit. Berdasarkan uraian penskoran tentang hasil data tes akhir ditemukan yang siswa yang memiliki keterampilan memanah dengan skor diatas rata-rata adalah sebanyak 8 orang $(33,33 \%)$ dan yang memiliki skor dalam rata-rata yaitu sebanyak 10 orang $(41,67 \%)$. Sedangkan siswa yang memiliki keterampilan memanah untuk dibawah skor rata-rata yakni 6 orang $(25 \%)$.

\section{Persyaratan Analisis}

Hasil uji normalitas data tentang semua variabel yang telah diuji hasilnya berdistribusi normal. Berdasarkan kriteria $\mathrm{L}_{\text {observasi }}\left(\mathrm{L}_{\mathrm{o}}\right)$ lebih kecil atau sama dengan $\mathrm{L}_{\text {tabel }}\left(\mathrm{L}_{\mathrm{t}}\right)$ berarti data berdistribusi normal, sebaliknya jika $\mathrm{L}_{\text {observasi }}\left(\mathrm{L}_{\mathrm{o}}\right)$ lebih besar dari $\mathrm{L}_{\text {tabel }}\left(\mathrm{L}_{\mathrm{t}}\right)$ berarti data tidak berdistribusi normal, karena masingmasing variabel probabilitasnya memenuhi kriteria $\mathrm{L}_{\text {observasi }}<\mathrm{L}_{\text {tabel. }}$ seperti yang diuraikan pada tabel berikut:

Tabel 2

Normalitas data

\begin{tabular}{ccccc}
\hline Data & N & Lo & Lt & Ket: \\
\hline $\begin{array}{c}\text { Tes } \\
\text { Awal }\end{array}$ & 24 & 0,105 & 0,173 & Normal \\
\hline $\begin{array}{c}\text { Tes } \\
\text { Akhir }\end{array}$ & 24 & 0,085 & 0,173 & Normal \\
\hline
\end{tabular}




\section{Pengujian Hipotesis}

Hipotesis yang diuji dalam penelitian ini adalah Pengaruh Metode latihan Sirkuit Terhadap Keterampilan memanah, hasil perhitungan menunjukkan bahwa

Tabel 3

Data Hipotesis

\begin{tabular}{llllll}
\hline Data & Mean & $\mathbf{t}_{\text {hitung }}$ & $\mathbf{t}_{\text {tabel }}$ & $\alpha$ & Ket: \\
\hline $\begin{array}{l}\text { Tes } \\
\text { Awal }\end{array}$ & 22,31 & 4,49 & 1,714 & 0,05 & Signifikan \\
\hline $\begin{array}{l}\text { Tes } \\
\text { Akhir }\end{array}$ & 26,04 & 4,49 & 1,714 & 0,05 & Signifikan \\
\hline
\end{tabular}

Berdasarkan perhitungan uji-t diatas, kita dapat melihat bahwa nilai $t_{\text {hitung }}$ adalah 4,49 sedangkan nilai $t_{\text {tabel }}$ dengan derajat kebebasan 24 (n-1) serta $(\alpha=$ $0,05)$ adalah 1,714. Karena $t_{\text {hitung }}(4,49)$ lebih besar dari $t_{\text {tabel }}(1,714)$ dapat diambil kesimpulan dari perbandingan tersebut bahwa metode latihan sirkuit memberikan pengaruh yang signifikan terhadap keterampilan memanah siswa ekstrakulikuler SDIT Auladi Kota Palembang.

\section{PEMBAHASAN}

\section{Pengaruh Metode Latihan Sirkuit Terhadap Keterampilan Memanah} Sekolah Dasar Islam Terpadu Auladi Kota Palembang.

Berdasarkan pengujian hipotesis terhadap hasil penelitian sesuai dengan hipotesis yang diajukan, sudah jelas bahwasanya metode latihan sirkuit memberikan pengaruh yang signifikan terhadap keterampilan memanah siswa ekstrakulikuler SDIT Auladi Kota Palembang. Metode latihan sirkuit yang diberikan kepada siswa merupakan penerapan dari pemberian latihan berupa teknik-teknik dasar yang di lakukan berdasarkan pos-pos tertentu untuk dilatih sesuai dengan beban yang diberikan. beberapa bentuk latihan dibuat sederhana, dan diterapkan dalam bentuk penguasaan teknik dasar panahan.

Menurut Akbar (2018) bahwa seorang pemanah harus dapat merasakan gerakan yang akan dilakukan disaat memanah, terutama dalam posisi berdiri, membidik sampai disaat melepaskan anak panah agar mengarah tepat kesasaran.

Selanjutnya dapat dilihat keterampilan siswa dalam melakukan latihan sirkuit, yang pasti sudah terlihat perubahan kemampuan penguasaan keterampilan teknik dasar memanah dari sebelumnya.

Sesuai pendapat dengan yang sampaikan oleh Syafruddin (2012) menyatakan bahwa " latihan merupakan realisasi atau pelaksanaan atau penerapan dari materi-materi latihan yang telah direncanakan sebelumnya, yang bertujuan untuk meningkatkan prestasi seseorang yang berlatih. Artinya latihan ialah suatu proses pelaksanaan berbagai materi yang disusun dan dilakukan secara berkelanjutan sesuai dengan keadaan yang berbeda dalam menuju suatu tujuan. 


\section{SIMPULAN}

Metode latihan sirkuit secara efektif memberikan pengaruh yang positif terhadap keterampilan memanah pada Sekolah Dasar Islam Terpadu Auladi Kota Palembang dengan uji hipotesis ditemukan $t_{\text {hitung }}$ besar dari $t_{\text {tabel }}$ dimana $t_{\text {hitung }} 4,49$ dari $t_{\text {tabel }}$ 1,714 Maka metode ini cukup tepat dijadikan sebagai pengganti metode latihan yang dilakukan sebelumnya guna mendapatkan hasil yang lebih baik dari sebelumnya.

\section{DAFTAR PUSTAKA}

Ahmad. (2008). Panahan. Jakarta: Ganeca Exact

Akbar, A., K. (2018). Analisis Persepsi Kinestetik terhadap Kemampuan Memanah Atlet Panahan Kota Palopo. Jurnal Penjaskesrek STKIP Mega Rezky.4(2). 115-127

Fikri, A. (2017). Meningkatkan Kebugaran jasmani melalui Metode Latihan Sirkuit dalam Pembelajaran Pendidikan Jasmani Olahraga dan Kesehatan di SMA Negeri 1 Lubuklinggau. Jurnal Pembelajaran Olahraga. 3(1). 89-102

Harsono. (1988). Prinsip-Prinsip Pelatihan. Jakarta: Depdikbud Dirjen Dikti P2LPTK.

Irawadi, H. (2010). Kondisi Fisik dan Pengukurannya. Padang: FIK Universitas Negeri Padang.

Kiram,Y.(1999). Belajar Motorik. Padang: FIK UNP Padang.

Sajoto. (1988). Pembinaan Kondisi Fisik Dalam Olahraga. Semarang : Dahara. Syafruddin. (2012). Ilmu Kepelatihan Olahraga. Padang: UNP Press. 